Borneo Journal of Sciences \& Technology, 4(1): 01-05

DOI: http://doi.org/10.3570/bjost.2022.4.1-01

e-ISSN: 2672-7439

(C) 2018, UTS Publisher.

Submitted: $08^{\text {th }}$ May $2021 \quad$ Accepted: $10^{\text {th }}$ October $2021 \quad$ Published: $31^{\text {st }}$ January 2022

\title{
Physical and Chemical Properties of Palm Oil Boiler Ash and Palm Oil Clinker Powder
}

\author{
${ }^{1}$ Euniza Jusli, ${ }^{2}$ Jen Hua Ling, ${ }^{2}$ Mastura Bujang and ${ }^{2}$ Dayang Siti Hazimmah Ali \\ ${ }^{1}$ Faculty of Engineering \& Quantity Surveying, INTI International University, \\ 71800 Nilai, Negeri Sembilan, Malaysia \\ ${ }^{2}$ Centre of Research for Innovation and Sustainable Development (CRISD), School of Engineering and \\ Technology, University of Technology Sarawak, 96000 Sibu, Sarawak, Malaysia
}

\begin{abstract}
Malaysia is known as one of the primary contributors to global oil palm production. The vast production of palm oil simultaneously intensifies the generation of biomass waste. This study characterized the physical properties of palm oil boiler ash (POBA) and palm oil clinker powder (POCP) such as density, specific gravity, particle size, morphology and chemical composition. The characterization was done using the density analyzer, field emission scanning electron microscopy (FESEM), and X-ray fluorescence (XRF). POBA and POCP had smaller particle sizes than Ordinary Portland Cement (OPC). Their structures were porous. The density and specific gravity of POBA and POCP were $52.7 \%$ and $28.6 \%$ lower than OPC. Containing $30.5 \%$ and $56.5 \%$ of silica dioxide $\left(\mathrm{SiO}_{2}\right), \mathrm{POBA}$ and POCP can trigger pozzolanic action in concrete to increase the strength of concrete. Overall, the POBA and POCP possess huge potential as supplementary cementitious materials, especially for lightweight brick and concrete.
\end{abstract}

Keywords: Palm oil boiler ash, Palm oil clinker powder.

\section{INTRODUCTION}

Malaysia is one of the world's leading palm oil producers. The country is undergoing robust development of the oil palm industry since the 1960s. In 2019, the oil palm plantation area in Malaysia reached 5.9 million hectares and Sarawak covered the largest planted area of $26.9 \%$ (1.59 million hectares) [1]. This commodity plays an important role in Malaysian economic growth contributing to $4.5 \%$ of national gross domestic product (GDP) and foreign exchange earnings of RM 67.5 billion [2];[3]. According to the Malaysian Palm Oil Board [1], the production of crude palm oil reached 19.86 million tonnes in 2019.

The enormous production of palm oil simultaneously generates an abundance of biomass wastes that created a major disposal problem. This included empty fruit bunch (EFB), mesocarp fiber (MF), palm kernel shell (PKS), oil palm fronts (OPF) and oil palm trunk (OPT) [4]. Among those, mesocarp fibre and kernel shell can be used as biomass fuel for steam boilers in palm oil mills [5]. The mesocarp fiber is produced from the palm oil extraction process while the kernel shells are obtained after the process of nut separation from its kernel. Boiler ash and clinker are obtained from burning the mesocarp fiber and kernel shells in the boiler. According to Mohamed et al. [6], the annual production of boiler ash was estimated to exceed 4 million tonnes.
Concrete is an essential construction material worldwide and the main binder is cement. In general, Portland cement is made of $80 \%$ limestone and $20 \%$ clay. The production of cement requires these materials to be burnt at a high temperature thus release massive $\mathrm{CO}_{2}$ due to the chemical decomposition of limestone. Benhelal et al. [7] reported that cement plants generate $5 \%$ to $7 \%$ of global $\mathrm{CO}_{2}$ emissions. The production of one tonne of cement releases about $900 \mathrm{~kg} \mathrm{CO}$ into the atmosphere. This impacts the environment in terms of global warming and climate change. Flatt et al. [8] discovered that the biggest challenges faced by human society are to minimize the environmental impact of concrete without compromising people's need for housing and infrastructure. Thus, the Malaysian government aspires to reduce approximately $50 \%$ of carbon emission intensity by 2025 [9].

Over the years, studies have been conducted to examine the feasibility of using POBA and POCP as supplementary cementitious material [8];[10-13]. This can be achieved by characterizing POBA and POCP. Knowing the physical properties and chemical compositions allows researchers to further understand the functions of POBA and POCP as supplementary cementitious materials in concrete. Thus, this study is carried out to investigate the physical properties and chemical compositions of POBA and POCP. 


\section{MATERIALS AND METHODS}

The palm oil boiler ash (POBA) and palm oil clinker (POC) used in this study were obtained from the palm oil mill in Mukah, Sarawak. The samples were in powder form (Figure 1) and stored in airtight containers.

The physical properties of POBA and palm oil clinker powder (POCP) such as density, specific gravity, particle size, and morphology were examined. The chemical properties were determined using an X-ray fluorescence (XRF) analyzer.

The density and specific gravity of POBA and POCP were determined according to ASTM D5550 [14]. The microstructures of POBA and POCP were observed using Hitachi SU8020 FESEM. Magnifications of 5k and $10 \mathrm{k}$ were used to analyze the microstructures of the samples with an operating power of $2 \mathrm{kV}$. The particle sizes for both materials were examined using Mastersizer 2000. The samples were also tested using Rigaku CG (EDXRF) elemental analyzer. From the analysis, the chemical compositions of POBA and POCP were obtained.

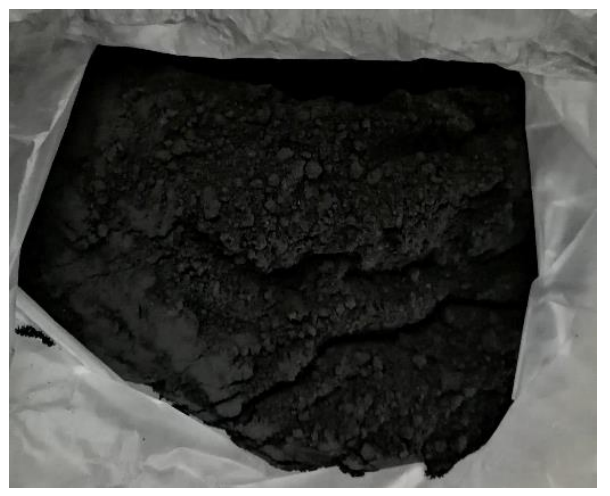

(a) Palm Oil Boiler Ash

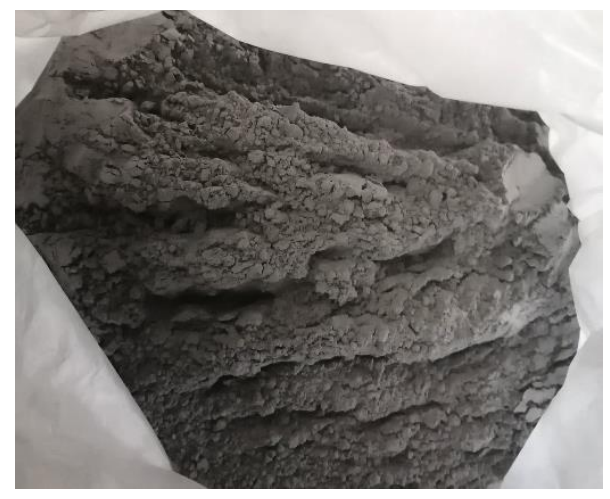

(b) Palm Oil Clinker Powder

Figure 1: Sample used in the laboratory

\section{RESULTS AND DISCUSSION}

\section{Density and Specific Gravity}

The density and specific gravity of POBA, POCP, and Ordinary Portland Cement (OPC) are presented in Table 1 . Based on the result, the density and specific gravity of POBA and POCP were $52.7 \%$ and $28.6 \%$ lower than OPC respectively. Density and specific gravity are the physical properties, which depend on the chemical composition, internal microporosity, particle size and specific surface area. The porous structure of the particles caused POBA and POCP to have a lower density and specific gravity than OPC. Abutaha et al. [15] reported that POCP is light and suitable to produce lightweight and green concrete.

Table 1: Density and specific gravity of POBA, $\mathrm{POCP}$, and OPC

\begin{tabular}{|l|c|c|}
\hline \multicolumn{1}{|c|}{ Material } & $\begin{array}{l}\text { Density } \\
\left(\mathbf{g} / \mathbf{c m}^{\mathbf{3}}\right)\end{array}$ & $\begin{array}{c}\text { Specific } \\
\text { Gravity }\end{array}$ \\
\hline Palm Oil Boiler Ash (POBA) & 1.4909 & 1.4938 \\
\hline $\begin{array}{l}\text { Palm Oil Clinker Powder } \\
\text { (POCP) }\end{array}$ & 2.2485 & 2.2528 \\
\hline $\begin{array}{l}\text { Ordinary Portland Cement } \\
\text { (OPC) }\end{array}$ & $3.1500^{\mathrm{a}}$ & 3.1561 \\
\hline
\end{tabular}

${ }^{\text {a Karim et al. [16] }}$

\section{Particle size}

The particle size distribution of POBA, POCP, and OPC are tabulated in Table 2. POBA recorded median particle size $D(v, 0.5)$ of $24.5 \mu \mathrm{m}$ and $364.3 \mathrm{~m}^{2} / \mathrm{kg}$ specific surface area. On the other hand, the $D(v, 0.5)$ of POCP was $11.3 \mu \mathrm{m}$ with a specific surface area of $807.4 \mathrm{~m}^{2} / \mathrm{kg}$. Generally, the fineness of POBA was close to cement. From the result, the particle of POCP was finer than POBA and OPC. The surface area per unit volume (or mass) increases as particle size decreases. Thus, larger surface area promotes rapid reaction especially during hydration process. This would further enhance the interfacial bonding between particles and the cement matrix [11].

Table 2: Particle size of POBA, POCP, and OPC

\begin{tabular}{|c|c|c|c|}
\hline Average Size $(\boldsymbol{\mu m})^{\mathbf{a}}$ & POBA & POCP & OPC $^{\mathbf{b}}$ \\
\hline$D(v, 0.1)$ & 6.36 & 2.76 & - \\
\hline$D(v, 0.5)$ & 24.5 & 11.3 & 27.98 \\
\hline$D(v, 0.9)$ & 105 & 788 & - \\
\hline $\begin{array}{c}\text { Specific surface } \\
\text { area }\left(\mathbf{m}^{2} / \mathbf{k g}\right)\end{array}$ & 364.3 & 807.4 & 331.0 \\
\hline
\end{tabular}

${ }^{\mathrm{a}} D=$ diameter, $v=$ volume, $0.1,0.5,0.9=$ percentage $(10 \%$, $50 \%$ and $90 \%$ respectively) of the particles are smaller than this diameter.

${ }^{\mathrm{b}}$ Kanadasan and Razak [17] 


\section{Morphology of POBA and POCP}

The morphology of POBA shown in Figure 2(a) was a porous structure filled with numerous oval and spherical poles of irregular sizes. From Figure 3(b), the particle of POCP was also irregular in shape but the pores were less visible (i.e. smaller and shallower) compared with POBA. According to Kow et al. [18], the pores may be due to the decomposition of the organic compounds in the fibres during the combustion process. The close-up of POBA and POCP in Figures 2(b) and 3(b) indicate that both materials had rough and flaky surfaces. Similar observations were obtained by Yahya et al. [19] and Kanadasan and Razak [17].

The generation of porosity, especially when due to small pores, can produce surface area far more than that produced only by reducing the particle size. This further increases the reaction rate to produce more hydration products.

On the other hand, a different particle shape of OPC was observed in Figure 4. The particle was irregular in shape with no visible pores. It showed that OPC particle was solid compared with POBA and POCP. The morphology of the materials correlated well with the results listed in Table 1. The porous structures of POBA and POCP affected their densities and specific gravities. POCP was less porous than POBA and thus its density and specific gravity were higher.
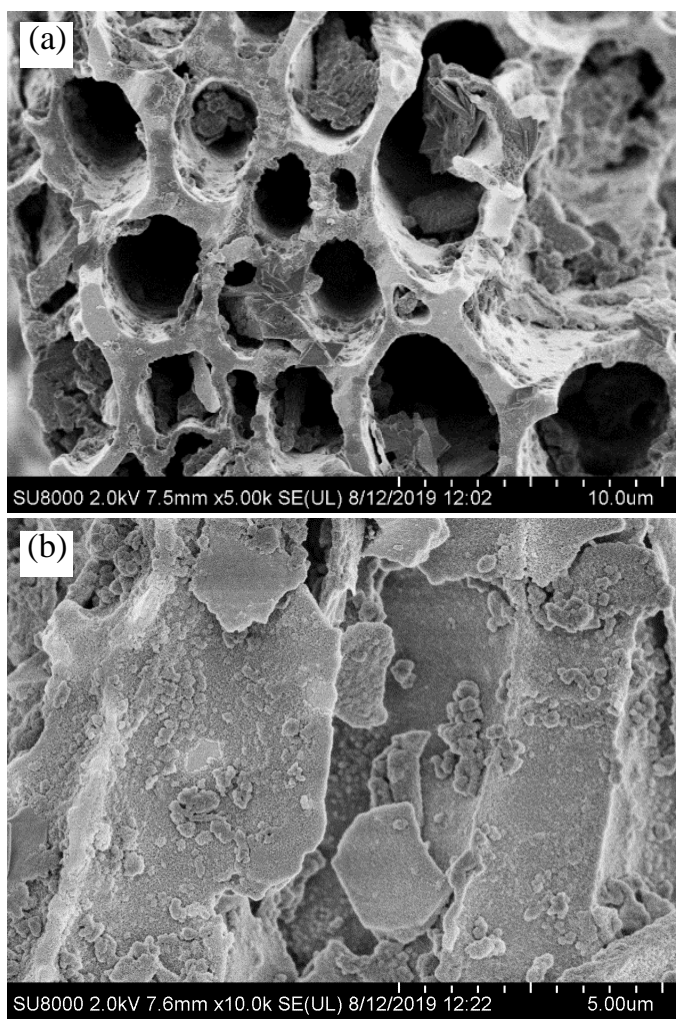

Figure 2: Morphology of palm oil boiler ash
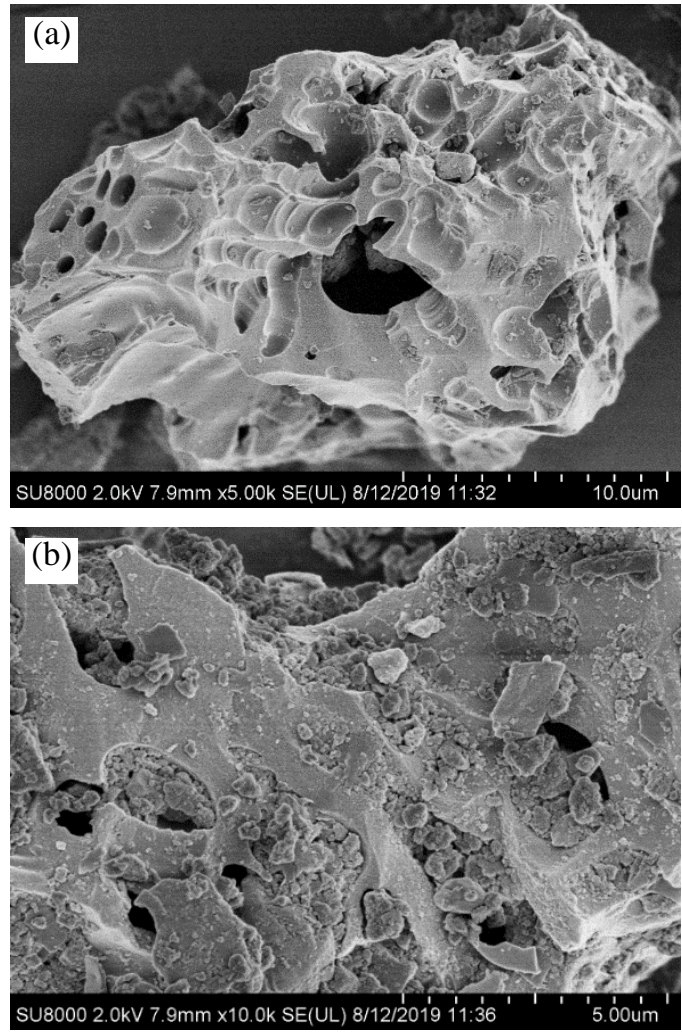

Figure 3: Morphology of palm oil clinker powder

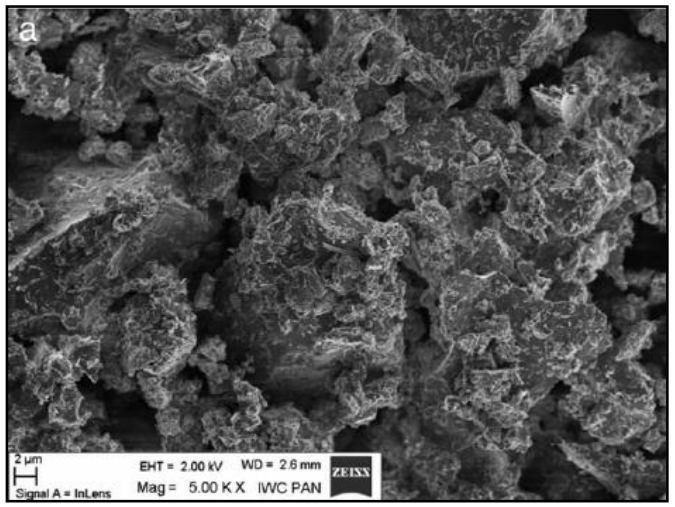

Figure 4: Morphology of cement type I [20]

\section{Chemical compositions}

The results of XRF analysis in Figure 5 exhibited that the main chemical composition of POBA was iron $\left(\mathrm{Fe}_{2} \mathrm{O}_{3}\right)$, followed by silica dioxide $\left(\mathrm{SiO}_{2}\right)$, potassium oxide $\left(\mathrm{K}_{2} \mathrm{O}\right)$, calcium oxide $(\mathrm{CaO})$. Meanwhile, $\mathrm{SiO}_{2}$ was the main component in POCP, followed by $\mathrm{CaO}$. Both components can influence the properties of fresh and hardened concrete.

POCP comprised $56.5 \% \quad \mathrm{SiO}_{2}$, which was the highest content compared with POBA and OPC of only $30.5 \%$ and $20.29 \%$ respectively. According to ACI Committee 234 [21], the concrete strength increased 
with the presence of $\mathrm{SiO}_{2}$ due to the pozzolanic action. Karim et al. [22] also observed the reaction between portlandite $\left(\mathrm{Ca}(\mathrm{OH})_{2}\right)$ and $\mathrm{SiO}_{2}$ of POCP that formed $\mathrm{C}$ $\mathrm{S}-\mathrm{H}$ gel for the strength development of concrete. Ahmmad et al. [13] and Subramaniam et al. [23] suggested the application of POBA and POCP as both pozzolan and filler materials to produce sustainable concrete and reduce the negative impact on the environment.

\section{CONCLUSION}

This study characterized the physical and mechanical properties of palm oil boiler ash (POBA) and palm oil clinker powder (POCP).
In terms of the physical properties, POBA appeared as a porous structure with oval and spherical poles of irregular sizes, whereas POCP was irregular in shape with smaller and shallower pores. For these pores, their densities and specific gravities were lower than OPC. The POCP particle was finer than POBA and OPC.

As for the chemical composition, POBA comprised mainly $\mathrm{Fe}_{2} \mathrm{O}_{3}$, which was followed by $\mathrm{SiO}_{2}, \mathrm{~K}_{2} \mathrm{O}$ and $\mathrm{CaO}$. The main composition of POCP was $\mathrm{SiO}_{2}$ and $\mathrm{CaO}$. $\mathrm{SiO}_{2}$ may be used to improve the strength of concrete through the pozzolanic action. For that, POBA and POCP can be used as the pozzolan and filler material for concrete.

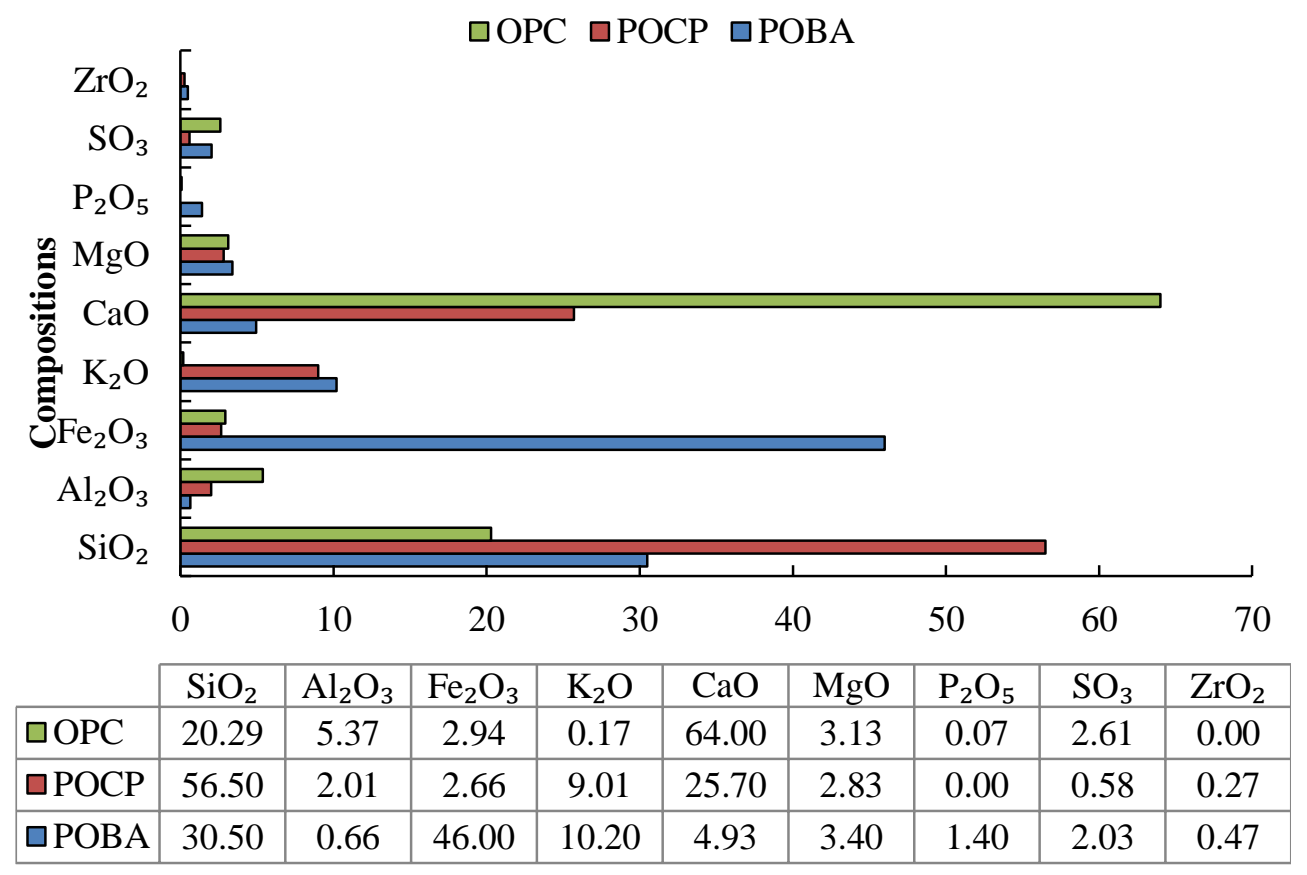

Percentage (\%)

Figure 5: Chemical composition of POBA, POCP, and OPC

\section{ACKNOWLEDGMENT}

The research work was funded by University of Technology Sarawak, UCTS/RESEARCH/4/2018/13.

\section{REFERENCES}

[1] Malaysian Palm Oil Board, Overview of the Malaysian Oil Palm Industry, 2019. www.mpob.gov. (Accessed Feb 2020).

[2] Nambiappan, B., Ismail, A., Hashim, N., Ismail, N., Shahari, D. N., Idris, N. A. N., Omar, N., Salleh, K. M., Hassan, N. A. M., Kushairi, A. 2018. Malaysia: 100 Years of Resilient Palm Oil Economic
Performance. Journal of Oil Palm Research, 30, 1325.

[3] Palm oil supply and demand outlook report 2020. 2020. Council of palm oil producing countries (CPOPC).

[4] Loh, S.K. 2017. The Potential of the Malaysian Oil Palm Biomass as a Renewable Energy Source, Energy Conversion and Management, 141, 285-298.

[5] Idris, J., Shirai, Y., Anduo, Y., Ali, A. A. M., Othman, M. R., Ibrahim, I., Husen, R., Hassan, M. A. 2015. Improved Yield and Higher Heating Value of Biochar from Oil Palm Biomass at Low Retention Time under Self-Sustained Carbonization. Journal of Cleaner Production, 104, 475-479. 
[6] Mohamed, A. R., Lee, K. T., Noor, N. M., Zainudin, N. F. 2005. Oil Palm Ash $/ \mathrm{Ca}(\mathrm{OH})_{2} / \mathrm{CaSO}_{4}$ Absorbent for Flue Gas Desulfurization. Chemical Engineering \& Technology, 28(8), 939-945.

[7] Benhelal, E., Zahedi, G., Shamsaei, E., Bahadori, A. 2013. Global Strategies and Potentials to Curb $\mathrm{CO}_{2}$ Emissions in Cement Industry. Journal of Cleaner Production, 51, 142-161.

[8] Flatt, R. J., Roussel, N., Cheeseman, C. R. 2012. Concrete: An Eco Material that Needs to be Improved. Journal of the European Ceramic Society, 32(11), 2787-2798.

[9] Ho, C. S., Matsuoka, Y., Chau, L. W., Teh, B. T., Simson, J. J., Gomi, K. 2013. Blueprint for the development of low carbon society scenarios for Asian regions- case study of Iskandar Malaysia, IOP Conference Series: Earth and Environmental Science 16, 012125.

[10] Ibrahim, H. A., Abdul Razak, H. 2016. Effect of Palm Oil Clinker Incorporation on Properties of Pervious Concrete. Construction and Building Materials, 115, 70-77.

[11] Roslan, A., Mohamed Yusof, M. K. T., Sharipudin, S. S., Michael, Z., Sharul Azhar, I. I. 2020. Feasibility Study of Palm Boiler Ash as Cement and Sand Replacement in Concrete. Journal of Engineering Science and Technology, 15(4), 23612378.

[12] Mo, K. H., Ling, T. C., Alengaram, U. J., Yap, S. P., Yuen, C. W. 2017. Overview of Supplementary Cementitious Materials Usage in Lightweight Aggregate Concrete. Construction and Building Materials, 139, 403-418.

[13] Ahmmad, R., Alengaram, U. J., Jumaat, M. Z., Sulong, N. H. R., Yusuf, M. O., Rehman, M. A. 2017. Feasibility Study on the Use of High Volume Palm Oil Clinker Waste in Environmental Friendly Lightweight Concrete. Construction and Building Materials, 135, 94-103.
[14] ASTM International. 2014. ASTM D5550 -14, Standard Test Method for Specific Gravity of Soil Solids by Gas Pycnometer.

[15] Abutaha, F., Abdul Razak, H., Kanadasan, J. 2016. Effect of Palm Oil Clinker (POC) Aggregates on Fresh and Hardened Properties of Concrete. Construction and Building Materials, 112, 416-423.

[16] Karim, M. R., Hashim, H., Abdul Razak, H., Yusoff, S. 2017. Characterization of Palm Oil Clinker Powder for Utilization in Cement-Based Applications. Construction and Building Materials, 135, 21-29.

[17] Kanadasan, J., Abdul Razak, H. 2015. Utilization of Palm Oil Clinker as Cement Replacement Material, Materials (Basel), 8(12), 8817-8838.

[18] Kow, K. W., Mun, L. Y., Yusoff, R. 2015. Silica Gel Synthesized from Oil Palm Boiler Ash. Journal of Mineral Metal and Material Engineering, 1, 14-18.

[19] Yahya, Z., Al Bakri Abdullah, M. M., Hussin, K., Ismail, K. N., Sandu, A. V., Vizureanu, P., Abd Razak, R. 2013. Chemical and Physical Characterization of Boiler Ash from Palm Oil Industry Waste for Geopolymer Composite. Revista de Chimie, 64(12), 1408-1412.

[20] Jóźwiak-Niedźwiedzka， D. 2015. Microscopic Observations of Self-Healing Products in Calcareous Fly Ash Mortars. Microscopy Research and Technique, 78(1), 22-29.

[21] ACI Committee 234. 2006. Guide for the Use of Silica Fume in Concrete, American Concrete Institute.

[22] Karim, M. R., Hashim, H., Abdul Razak, H. 2016. Assessment of Pozzolanic Activity of Palm Oil Clinker Powder. Construction and Building Materials, 127, 335-343.

[23] Subramaniam, V., Ngan, M. A., May, C. Y., Sulaiman, N. M. N. 2008. Environmental Performance of the Milling Process of Malaysian Palm Oil Using the Life Cycle Assessment Approach. American Journal of Environmental Sciences, 4(4), 310-315. 